\title{
Rethinking Emotions and Destination Experience: An Extended Model of Goal-Directed Behavior
}

\author{
Kamran Huseynov \\ NOVA Information Management School (NOVA IMS), Universidade Nova de Lisboa \\ Diego Costa Pinto \\ NOVA Information Management School (NOVA IMS), Universidade Nova de Lisboa \\ Márcia Maurer Herter \\ Universidade Europeia, UNIDCOM/IADE
}

Paulo Rita

NOVA Information Management School (NOVA IMS), Universidade Nova de Lisboa

This is the accepted author manuscript of the following article published by Sage:

Huseynov, K., Costa Pinto, D., Maurer Herter, M., \& Rita, P. (2020). Rethinking Emotions and Destination Experience: An Extended Model of GoalDirected Behavior. Journal of Hospitality \& Tourism Research. https://doi.org/10.1177/1096348020936334

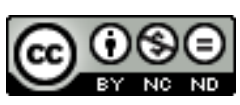

This work is licensed under a Creative Commons Attribution-NonCommercialNoDerivatives 4.0 International License. 


\title{
RETHINKING EMOTIONS AND DESTINATION EXPERIENCE: AN EXTENDED MODEL OF GOAL-DIRECTED BEHAVIOR
}

\begin{abstract}
This research aims to extend the model of goal-directed behavior (EMGB), by deepening its emotional path and including new variables to predict tourist behavioral intention: hedonism, destination experience, and tourism innovativeness. Based on a final sample of 457 European tourist nationals, we tested the hypotheses using Partial Least Squares Structural Equations Modeling (PLS-SEM). The findings showed the significant influence of hedonism and tourism innovativeness on tourist desire. In addition, findings uncover the mediating role of hedonism on the emotional path. The findings also extend previous research by revealing that not all destination experience dimensions (sensory, affective, behavioral, and intellectual) equally influence tourist behavioral intention. Indeed, only sensory and intellectual destination experience dimensions were found to affect behavioral intention. The findings have important implications for tourism managers crafting destination experiences and contribute to tourism research by presenting a more comprehensive framework of goal-directed behavior applied to tourism.
\end{abstract}

Keywords: model of goal-directed behavior; hedonism; destination experience; tourism innovativeness; tourism research; amusement parks. 


\section{INTRODUCTION}

Tourism is one of the largest industries in the world (Williams, 1998), it is an important sector for economic growth in many countries (Horng et al., 2012; Stylos et al., 2016). According to the World Tourism Organization (UNWTO, 2019), around $19 \%$ of the world's population traveled to different countries in 2018. For instance, Europe is responsible for half of global tourism, receiving 710 million international tourists a year which represents annual revenue of 514 billion euros (UNWTO, 2019). Due to the economic relevance of tourism, there is growing academic and practical interest in tourism attractions to generate tourist behavioral intention. However, despite its relevance, past research acknowledges the difficulty of anticipating tourist behavioral intention (Lee et al., 2012), suggesting the need for more insights to deepen its understanding and prediction capability.

To fill this gap, this research draws on the model of goal-directed behavior (MGB), considered one of the most appropriate for analyzing tourist behavioral intention (e.g., Han \& Ryu, 2012; Meng \& Choi, 2016; Song et al. 2014). One of the main characteristics of this model (Perugini \& Bagozzi, 2001) is the emotional path (positive emotions $\rightarrow$ desire $\rightarrow$ behavioral intention), which we propose plays a key role in predicting tourist behavioral intention. Nevertheless, crucial elements related to tourist behavioral intention were disregarded from the original MGB model such as the emotional elements and important tourism-related variables (e.g., destination experience). Thus, the present study aims to extend the MGB model by deepening the emotional path 
and by including new variables such as hedonism, destination experience, and tourism innovativeness.

First, previous research focused on specific tourism-related variables but did not explore their combined effect on tourist behavioral intention. For instance, Malone et al. (2014) explored the role of hedonism in improving tourism behavioral intention. Moreover, Pikkemaat and Schuckert (2007) focused on destination experience of tourist attractions as an important predictor of behavioral intention. Finally, Martin and Herrero's (2012) findings indicated that tourism innovativeness positively influenced behavioral intentions. By doing so, this research contributes to previous research by jointly analyzing the relative impact of hedonism, destination experience, and tourism innovativeness to predict tourist behavioral intention, expanding the original MGB model.

Second, the present study also contributes to the literature by deepening the emotional path of the MGB model. Past research has explored the antecedents of emotions from tourism experiences (Malone et al., 2014). We investigate enjoyment and emotional involvement as two new factors, beyond positive emotions, to influence tourists' desire and behavioral intentions.

Third, we explore the mediating role of hedonism between emotional elements (positive emotions, emotional involvement, level of enjoyment) and tourists' desire. The prior research analyzed hedonism in understanding consumers' behavioral intentions in different contexts, such as festivals (Grappi \& Montanari, 2011; Gursoy et al., 2006), volunteer travels (Strzelecka et al., 2017) as well as adopting mobile services in hospitality (Rita et al., 2018) but 
did not explore its mediating role. We contribute by analyzing the mediating role of hedonism on the emotional path of the MGB model: emotional elements $\rightarrow$ hedonism $\rightarrow$ desire $\rightarrow$ behavioral intention.

Finally, this research also discusses the practical implications for tourism managers on how to improve tourist behavioral intention. Tourism managers aim to understand the tourists' desires and intentions (Perugini \& Bagozzi, 2001; Salazar et al., 2010) to be able to improve their offers. For instance, destination experience has been increasing its importance in the tourism literature and practice (e.g., Barnes et al., 2014; Ingram et al., 2017; Oliveira et al., 2019; Wearing \& Foley, 2017). Forbes' (2019) Megatrends in Tourism suggests that experience is at the core of the sector's value proposition and can generate around $\$ 4.2$ trillion by 2028 . Furthermore, Harvard Business Review (2015) suggests that innovation in tourism is the next crop of opportunities to expand the company's reach and economic value. Therefore, this research provides insights for managers on how to tackle tourist's hedonism, innovativeness, and specific destination experience dimensions (sensory, affective, behavioral, and intellectual) to improve tourist behavioral intention.

\section{CONCEPTUAL MODEL AND RESEARCH HYPOTHESES}

The model of goal-directed behavior (MGB), proposed by Perugini and Bagozzi (2001), incorporates desire and emotional components (such as positive emotions) to the previous theory of planned behavior (Ajzen, 1985). Extant research shows that the MGB model is more accurate in terms of 
explanatory and predicting power compared to its predecessors (Poels \& Dewitte, 2008; Taylor, 2007; Taylor et al., 2009), increasingly being applied to the tourism context to behavioral intention (e.g., Taylor, 2007). However, despite several studies using the MGB model in tourism (Choi \& Park, 2017; Han \& Ryu, 2012; Lee \& Back, 2008), some findings suggest that the original MGB variables are not relevant in tourism contexts, such as the subjective norms (Park et al., 2017), the perceived behavioral control (Choi \& Park, 2017), the negative emotions (Song et al., 2012), and the frequency of past behavior (Lee et al., 2012). Therefore, the MGB model can be revised to offer a better fit while considering the tourism context.

Thus, this research proposed an extended version of the MGB model, by deepening its emotional path and including relevant tourism-related variables such as hedonism (Babin et al., 1994), destination experience (Brakus et al., 2009), and tourism innovativeness (Goldsmith \& Hofacker, 1991). These new variables were included in the MGB model because of its suggested predicting power in previous research on tourist behavioral intention (e.g., Pikkemaat \& Schuckert, 2007). Next, we conceptualize and hypothesize the relationships to each of these variables, proposing an extended MGB model to predict tourist behavioral intention.

Hedonism

Hedonism is considered an important factor for consumers when evaluating a consumption experience (Babin et al., 1994). Hedonism is related to pleasure, enjoyment, entertainment, or relaxation which are elements closely associated with consumers when searching for travel (Hirschman \& Holbrook, 
1982). Hedonism has been largely explored in the tourism field through empirical studies such as theme parks (Bigné et al., 2005), restaurant services (Babin et al., 2005; Han et al., 2010), festivals (Grappi \& Montanari, 2011), casino-hotels (lo, 2016), and volunteer travels (Strzelecka et al., 2017). Research shows that higher hedonic experiences increase tourist satisfaction, behavioral intention, and word of mouth (Gnoth, 1997; Zins, 2002).

According to tourism research, hedonism comprises three main constructs: positive emotions (Bigné et al., 2005; lo, 2016; Kwortnik \& Ross, 2007), emotional involvement (Huang et al., 2013), and enjoyment (Babin et al., 2005; Grappi \& Montanari, 2011). Pearce (2009) showed that emotions play a crucial role in shaping tourist hedonic experiences. Furthermore, Grappi and Montanari (2011) suggested that positive emotions had a significant impact on hedonism in a festival. Hence, considering previous literature, we propose the following hypothesis:

H10: Positive emotions do not affect hedonism.

H1: Positive emotions have a positive effect on hedonism.

Ragheb (1996) supported the idea of enjoyment as the main component of the hedonic experience, while Babin et al. (1994) described enjoyment as an essential feature of hedonic value. Previous studies suggested that enjoyment is a benefit from emotional (Babin et al., 1994; Hirschman \& Holbrook, 1982) and consumption experiences (Gilbert and Wilson, 2007), which in turn affects the measurement of hedonic value (Gilbert and Wilson, 2007). Various scholars explored enjoyment as a variable capable of enhancing hedonic experiences in 
different contexts such as technology (Davis et al., 1992; Shen \& Eder, 2009; Yi \& Hwang, 2003) and retail (Childers et al., 2001). Likewise, since enjoyment has a positive influence on hedonic experience, consumers enhance their outputs like positive attitudes (Childers et al., 2001) and behavioral intentions (Guo \& Barnes, 2011; Shen \& Eder, 2009). Thus, according to previous literature, the present research proposes the following hypothesis:

H20: Enjoyment does not affect hedonism.

H2: Enjoyment has a positive effect on hedonism.

Another element of hedonic experiences is emotional involvement (Holbrook, 1980). Zaichkowsky (1985) defined involvement as the perceived motivation of a person to an object based on the inherent values, needs, and interests. Consistently, Holsapple and Wu (2007) described emotional involvement as a term, which is used to express individuals' behavior involving their emotions in their acts. Britto and Alencar (2013) explored the role of emotional involvement in the adventure tourism context, suggesting that adventure tourists are highly emotionally involved (usually anxious) while carrying out hazardous activities. Furthermore, research showed that emotional involvement is one of the main aspects influencing the audience of a TV show to visit the film destinations, as it has a significant impact on consumer choices (Kim, 2011).

Additionally, Huang et al. (2013) suggested that emotional involvement is a key factor of influence on tourist behavioral intention. In line with previous studies, we hypothesize that: 
$H 30$ : Emotional involvement does not affect hedonism.

H3: Emotional involvement has a positive effect on hedonism.

Travelers seek hedonic experiences when they consume tourism products to get pleasure, enjoyment, entertainment, or relaxation (Hirschman \& Holbrook, 1982). Studies in the tourism field explored the effects of positive emotions and tourist behavioral intentions (Bigné et al., 2005) and the relationship between positive emotional experiences with satisfaction and the decision-making process (Han et al., 2010). Following the hedonism theories discussed above (Grappi \& Montanari, 2011; Hosany \& Gilbert 2009; lo, 2016; Malone et al. 2014), we postulate that hedonism would have a mediating role between emotional factors and desire. Thus, we propose the following hypothesis.

H40: Hedonism does not affect desire.

H4: Hedonism has a positive effect on desire.

\section{Tourism Innovativeness}

The origin of the innovativeness concept is assigned to Roger (1962) who is recognized as the founder of innovativeness (diffusion) theory (e.g., Ganglmair-Wooliscroft \& Wooliscroft, 2016; Goldsmith \& Hofacker, 1991). Innovativeness is described as an influencing element in behavior, in a way that the willingness to adopt a new service or product increases (Hirschman, 1980). Innovativeness has also been empirically related to tourism as a factor that supports travelers for information seeking, booking, and payment processes 
(Flynn \& Goldsmith, 1993; Goldsmith \& Litvin, 1999; Kim et al., 2019; Li \& Buhalis, 2006; Ozturk et al., 2016; Pereira et al., 2016).

During the last few decades, numerous scholars attempted to create a scale to measure innovativeness. According to Roehrich (2004), it is possible to divide it into two groups. The first one is "life innovativeness" (Hurt et al., 1977; Kirton, 1976), which mainly analyzes the interest on any novelty, and the other "adoptive innovativeness" (Goldsmith \& Hofacker, 1991; Raju, 1980; Roehrich, 1994), which focuses on new product adoption. Goldsmith and Hofacker (1991) criticized the global (life) innovativeness for its low predictive power in specific products. Hence, these authors developed a new scale called "domain-specific innovativeness" (DSI), which can be used to predict the innovation within a narrow domain of interest.

Researchers supported these ideas by confirming the domain-specific innovativeness as a stronger predictor of innovativeness instead of its antecedents (Bartels \& Reindeers, 2011; Hoffmann \& Soyuz, 2010; Roerich, 2004). Along with that confirmation, many scholars have also employed domain-specific innovativeness in their studies. For example, in the context of information technologies, innovativeness was illustrated as a major moderator between salient perceptions (ease of use, usefulness) and usage intentions (Agarwal \& Prasad, 1998). Noh et al. (2014) explored the attitudes and innovativeness of young consumers toward newly released products. Results suggested that innovative consumers with a high income have more desire to buy new cool products rather than old-fashioned consumers.

The domain-specific innovativeness (DSI) scale has also been empirically tested in the tourism context such as in information-seeking behavior 
(Flynn \& Goldsmith, 1993), online travel booking (Li \& Buhalis, 2006), and usage of travel agencies (Goldsmith \& Litvin, 1999). Furthermore, Couture et al. (2015) utilized DSI as "tourism-specific consumer innovativeness (TI)" in their research and revealed that it has a significant impact on tourist behavior. Research showed that tourism innovativeness and hotel bookings have a significant impact on tourists' behavioral intentions (e.g., Ozturk et al., 2016; Slade et al., 2015; Thakur \& Stratislava, 2014). Thus, in line with the previous literature, we used the scale of tourism innovativeness (Couture et al., 2015) and propose the following hypothesis.

H50: Tourism Innovativeness does not affect desire.

H5: Tourism Innovativeness has a positive effect on desire.

\section{Destination Experience Dimensions}

Schmitt et al. (2015) suggested that consumers do not only buy products but also buy experiences, which play a crucial role in their satisfaction and future behavioral intentions. For Brakus et al. (2009), the experience is a subjective and internal consumer response (sensation, feeling, and cognition).

The experience construct is composed of four dimensions: sensory, affective, behavioral, and intellectual. The sensory dimension is linked to aspects of the brand that generate experiences through the consumer's five senses - smell, touch, taste, sight, and hearing (Brakus et al., 2009; Schmitt, 1999). The affective dimension relates to the moods and emotions evoked by a brand (Brakus et al., 2009; Schmitt, 1999). The intellectual dimension is a consequence of the cognitive associations with the brand (Brakus et al., 2009). 
Finally, the behavioral dimension is associated with the physical experience of interacting with the brand (Brakus et al., 2009).

Experience has already been examined in different frameworks, such as products, services, places, retail as well as tourism destinations. For instance, Moreira et al. (2017) showed that sensory stimuli related experience and purchase intention. Khan and Rahman (2015) focused on analyzing affective relations (guest-to-guest relations) to enhance hotel experiences. Furthermore, the experience was studied for both place (Beckman et al., 2013) and destination experience (Barnes et al., 2014) employing the scale developed by Brakus et al. (2009). Both studies indicated that experience has a significant impact on behavioral intentions, especially the sensory experience being a key factor in shaping the tourist decision-making process. In line with previous studies, we formulate the following hypotheses:

H60: Experience dimensions do not affect behavioral intention.

H6a: Sensory Experience has a positive effect on behavioral intention.

H6b: Affective Experience has a positive effect on behavioral intention.

H6c: Behavioral Experience has a positive effect on behavioral intention.

H6d: Intellectual Experience has a positive effect on behavioral intention.

Desire

Desire was considered as an omitted variable in the antecedents of the goal-directed behavior model (Bagozzi, 1992; Lee et al., 2012; Perugini \& Bagozzi, 2001; Song et al., 2012). Research indicated that in case of having a 
desire for a specific action, individuals are more motivated to perform the related behavior (Song et al., 2014). Perugini and Bagozzi (2001) demonstrated that desire is a critical variable that has the largest impact on behavioral intention and that the intention thoughts are not strongly formed without having a desire. Besides, the results of numerous studies also showed the importance of desire in exploring behavioral intentions (e.g., Choi \& Park, 2017; Meng \& Choi, 2016; Song et al., 2012). Specifically, research on tourism suggested that desire plays a significant role in the decision-making process of tourists (Lee et al., 2012; Song et al., 2014). Thus, we hypothesize as follows:

$\mathrm{H} 70$ : Desire does not affect behavioral intention.

H7: Desire has a positive effect on behavioral intention.

Figure 1 presents the conceptual model and the proposed research hypotheses.

Insert Figure 1 about here

METHOD

This study employed quantitative research to analyze the extended model of goal-directed behavior (EMGB), including new variables, such as 
hedonism, destination experience, and tourism innovativeness. As per previous tourism studies, an online survey of European tourists of different nationalities was conducted (Han et al., 2009; Lee et al., 2012). Since we aimed to explore the emotional experiences of tourists, the final sample was composed of only European nationals who visited an amusement park in the last ten years.

Respondents were approached using a convenience sampling method. The survey was disseminated via major social networking websites (e.g., Facebook, Messenger) and a pool of participants of a major European University. This initial sample was mostly composed of university students (32\% undergraduates and $37 \%$ post-graduates). The second wave of data collection used a European online panel (Prolific Academic) to increase the external generalizability of results (beyond university students) and to increase sample size and nationality diversity. The data was collected using a university panel of respondents and an online panel sample. Important, there were no significant differences related to sample origin (university panel or online panel) impacting the results.

In total, 27 European nationalities were represented in the final dataset (e.g., Portugal, France, Italy, Germany, Poland, Netherlands, UK, Spain). Twenty-nine participants were excluded because our focus was exclusively on European nationals (not on EU residents). Thus, based on a final sample of 457 European tourist nationals, we tested the hypotheses using Partial Least Squares Structural Equations Modeling (PLS-SEM).

Research Context 
Tourism is a compelling industry in which the economy of many countries relies upon becoming a major tourist destination (Page, 2003). The availability of tourist attractions is a key factor of a destination to have constant visitors. There are two main roles of tourist attractions in this industry: first, they encourage tourists to travel to a specific destination; second, they fulfill the expectations of visitors (Gunn, 1994). Of interest to this research, the amusement park industry goes back to 1583 when Bakken park opened in Copenhagen, Denmark, which is still in operation being "the oldest amusement park in the world" (Pearce, 1988). "Amusement parks are extreme examples of capital intensive, highly developed, user-oriented, man-modified, recreational environments" (Pearce, 1988, p.60). This new concept became famous very fast and attracted more visitors because of its service quality and appealing emotions and experiences.

Currently, amusement parks can be found almost all over the world and they are some of the leading attractions of the tourism industry (Formica \& Olsen, 1998). According to Wylson and Wylson (1994), there are two purposes associated to an amusement park: the primary objective is to amuse and provide an extraordinary experience, which requires various attractions with unique motives; the second goal is to give a recreation experience, which requires having food and beverage, relaxation areas, natural and social environments. Milman (2008) stated that the diversity of attraction types and experiences plays a crucial role in the success of an amusement park.

Research in amusement parks can be considered a recent field. Most of the studies have been limited to Walt Disney's company and from the 
perspectives of American theme parks (e.g., Cornelis, 2010). Furthermore, past research mostly analyzed the opinion of visitors to an existing park. However, previous studies did not explore the factors that predict prospective tourist behavioral intentions. Hence, this study sheds more light on predicting the behavioral intention of tourists in the context of amusement parks by employing an extended version of the model of goal-directed behavior (EMGB), broadening its emotional path and including new variables (hedonism, destination experience, and tourism innovativeness).

\section{Measures}

The questionnaire was composed of three main sections. First, participants read the study description and answered to a filter question, in which respondents indicated if they visited an amusement park or not. As the aim of the study was to achieve tourist behavioral intentions towards an amusement park, the filter question was set up to assess the eligibility of the respondents. Participants that did not fit the research profile (who did not visit an amusement park at least once in their lifetime) or had incomplete responses were excluded from the analysis (PLS-SEM procedures).

The second section focused on measuring the variables enjoyment ( 4 items, Huang et al.,2013), positive emotions (7 items, Huang et al., 2013), emotional involvement (3 items, Huang et al., 2013), hedonism (4 items, Grappi and Montanari, 2011), destination experience (12 items, Barnes et al., 2014), tourism innovativeness (6 items, Couture et al., 2015), desire (4 items, Song et al., 2014), and behavioral intention (3 items, Song et al., 2014) in a seven-point 
Likert scale (Donilcar, 2013), where "1" means strongly disagree and "7" stands for strongly agree. We considered behavioral intention because all participants in the final sample have had at least one previous visit to amusement parks, with about $72 \%$ visiting more than four times. Table 1 shows the items of each variable adapted to the tourism context and Table 5 presents all scales' reliability. Finally, the third section assessed the participants' sociodemographic characteristics.

The questionnaire was pre-tested to verify its understandability with 14 participants with similar backgrounds as the target study population. No modification was necessary as the questionnaire was considered clear and understandable by the participants.

Data Analysis

Partial Least Square Structural Equation Modeling (PLS-SEM) was employed using the SmartPLS 3.0 software (Ringle et al., 2014). The PLS-SEM method is the most appropriate one for using both the reflective and formative constructs in the same research model (Hair et al., 2010). The study followed the procedure suggested by Henseler et al (2015), who indicated that assessment of the measurement model should be achieved by evaluating the 
structural model. The following sections present the findings of the PLS-SEM model.

\section{RESULTS}

Sample characteristics

Table 2 shows the demographic characteristics of the respondents. The final sample $(n=457)$ had a higher proportion of females $(59 \%)$ compared to males (41\%). The most frequently reported age groups were between 22-25 (36\%) and 26-35 (32\%), while other groups were represented in smaller proportions. Our sample is consistent with most amusement park visitors that are between 22 and 55 years old (Editorial, 2006). Moreover, most of the respondents held an undergraduate (32\%) or a postgraduate $(37 \%)$ degree, since most of the sample was over 25 years. Concerning marital status, almost half of the sample reported that they were single (45\%), following by respondents already in a relationship (34\%), married (19\%), and divorced/widowed (2\%). The monthly income distribution in euros was $0-550$ (30\%), 551-950 (23\%), 951-1,350 (22\%), and above 1,350 (25\%).

Insert Table 2 about here 
The information on the sample's traveling habits is presented in Table 3. Respondents were traveling at least once (28\%), twice (39\%), or more than three times (24\%) a year with a large percentage having a travel duration of one to two weeks (58\%) or less than a week (32\%). Respondents were also questioned regarding their amusement park visiting frequency, where most of them indicated that they had visited an amusement park 4 to 6 times (38\%), while others had been 1 to 3 times (28\%), 7 to 9 times (13\%) or more than ten times (21\%). Accordingly, their last visit to the amusement park was not also a long time ago, as $85 \%$ of participants had been to an amusement park less than five years ago. Moreover, the average budget that respondents were willing to spend in an amusement park was 107 euros per person.

Insert Table 3 about here

Measurement model

Reliability and validity measures were established from existing literature to confirm the validity of the used model. As the measurement model was developed based on reflective constructs, we evaluated the model by indicator reliability, internal consistency, convergent validity, and discriminant validity (Henseler et al., 2009). 
First, the indicator reliability was measured by t-statistic results (obtained by bootstrapping with 5,000 iterations) and factor loadings. All indicator loadings were statically significant $(p<0.01)$. Henseler et al. (2009) illustrated that the factor loadings of each indicator should be higher than 0.70 , while Hair et al. (2010) pointed out 0.5 as a minimum threshold. In this model, all factor loadings were above 0.70 , except BE3, IE2, and PE5. As the values were above 0.40 , the variables remained in the model for the examination with other measurement factors. Composite reliability $(\mathrm{CR})$ was also assessed to achieve the complete results of internal consistency, with a minimum value of 0.80 , with all the variables, except $\mathrm{BE}(0.783)$ being above the criteria determined by Henseler et al. (2009). All variables remained in the model since the loadings were within the acceptable threshold (above 0.50), statistically significant $(p<0.01)$ and the $C R$ values were almost above the minimum threshold, along with the fact that there were no serious changes in the results by the exclusion of BE. Table 4, showing the results of t-statistics and factor loadings, and Table 5, presenting findings of $\mathrm{CR}$ suggest indicator and composite reliability. 
Second, the convergent validity was evaluated by average variance extracted (AVE). It was assumed that the values of AVE should be more than 0.50 for explaining at least half of the variance of the original indicators (Götz et al., 2010; Henseler et al., 2009). All the AVE values were above the minimum threshold of 0.50 , as summarized in Table 5 .

Insert Table 5 about here

Finally, the discriminant validity was assessed by three different criteria: Fornell-Larcker criterion (Fornell \& Larcker, 1981), Cross-loadings (Hair et al., 2010) and the heterotrait-monotrait ratio (HTMT, Henseler et al., 2015). The first measure of discriminant validity was presented in Table 5 by calculating the square root of $A V E$ and ensuring that the estimated values were greater than the correlations between variables (Fornell \& Larcker, 1981). Another indicator was cross-loading assessment, which specifies that all the loadings should be larger than its cross-loadings (Hair et al., 2010). The results of this analysis reported an issue with BE3 and PE5 variables (Appendix 1), which were below their cross-loadings. Moreover, Henseler et al. (2015) developed a measure called heterotrait-monotrait ratio (HTMT) for discrimination of two factors of the model. The maximum threshold was defined as one (Henseler et al., 2016), which is also shown in Table 6. Eventually, the discriminant validity of the model was proved, based on the criteria as mentioned above from literature. 
Due to internal consistency and discriminant validity issues, the model was tested by eliminating the PE5 and BE3 indicators. As there was not any significant difference in the results, the proposed model included all the measurement indicators.

Structural model

As all the reliability and validity measures were achieved positively, it was possible to begin the structural model analysis. In this part of the research, the model was examined with three different criteria: multicollinearity checking (VIF; Hair et al., 2010), explained variation criteria ( $R^{2}$; Chin, 1998), and significance of the path coefficients (t-statistics). The results indicated that there was not any multicollinearity issue as the values were below ten, ranging between 1.111 and 8.637 (Hair et al., 2010). Furthermore, the $R^{2}$ values of the dependent variables, hedonic value (0.679), desire (0.642) and behavioral intention (0.809) were also far above the minimum threshold (0.2) that was suggested by Chin (1998).

Finally, bootstrapping (5,000 iterations) was computed to achieve the degree of significance of path coefficients. All the direct effects were statistically significant in predicting Hedonism (HE) as follows: positive emotions $\left(\beta_{\mathrm{PE} \rightarrow \mathrm{HE}}=\right.$ 
0.499, $p<0.01)$; enjoyment $(\beta E N \rightarrow H E=0.271, p<0.01)$; emotional involvement $\left(\beta_{E I \rightarrow H E}=0.122, p<0.01\right)$, which support $\mathrm{H} 1, \mathrm{H} 2$, and $\mathrm{H} 3$. Moreover, findings indicated that hedonism $\left(\beta_{H E} \rightarrow \mathrm{DE}=0.534, \mathrm{p}<0.01\right)$ and tourism innovativeness $(\beta \mathrm{TI} \rightarrow \mathrm{DE}=0.348,<0.01)$ positively affected desire. Also, results showed that there was a significant positive relationship between desire and behavioral intention $(\beta D E \rightarrow I R=0.852, p<0.01)$, sensory experience and behavioral intention $(\beta S E \rightarrow I R=0.081, p<0.01)$ as well as intellectual experience and behavioral intention $\left(\beta_{\mathrm{IE} \rightarrow \mathrm{IR}}=0.075, \mathrm{p}<0.01\right)$. However, affective and behavioral experiences did not have a positive influence on behavioral intention. Thus, $\mathrm{H} 4$, $\mathrm{H} 5, \mathrm{H} 6 \mathrm{a}, \mathrm{H} 6 \mathrm{~d}$, and $\mathrm{H} 7$ were also supported, while $\mathrm{H} 6 \mathrm{~b}$ and $\mathrm{H} 6 \mathrm{c}$ were not. We elaborate on the implications of the insignificant impacts of affective and behavioral experiences for tourism in the discussion session.

Overall, the model explains $80.9 \%$ of the variation of behavioral intention and eight out of ten hypotheses were supported, and the corresponding null hypotheses rejected. An overview of the research model and achieved results are depicted in Figure 2.

Insert Figure 2 about here

Additionally, we also investigated the indirect and total effects of each variable in Table 7. Regarding the prediction of behavioral intention, desire was the most powerful factor with the largest total effect $\left(\beta_{D E} \rightarrow \mathbb{R}=0.852, p<0.01\right)$, followed by hedonism $\left(\beta_{H E \rightarrow I R}=0.455, p<0.01\right)$, tourism innovativeness $(\beta T I \rightarrow I R$ 
$=0.296, p<0.01)$, and positive emotions $(\beta P E \rightarrow \mathbb{R}=227, p<0.01)$. The same trend was also followed in the prediction of latent variable desire with slightly higher effects and indicating hedonism as the most powerful antecedent.

Insert Table 7 about here

\section{DISCUSSION}

The findings indicate that the new conceptual model has strong predictive power regarding tourists' desire and behavioral intentions. A key contribution of this research is extending the goal-directed behavior model (Perugini \& Bagozzi, 2001) by including hedonism, destination experience, and tourism innovativeness constructs to account for a full understanding of tourist behavior. It is important to note that, in comparison with some previous studies that used extensions of MGB in tourism research (e.g., Meng \& Choi, 2016; See et al., 2012), our results show significantly better predictive power over tourists' behavioral intentions.

Theoretical Implications 
Theoretically, this research makes four important contributions to the tourism literature. First, results suggest that the proposed conceptual model has significant predictive power in explaining behavioral intention. This new extended model of goal-directed behavior (EMGB) incorporates hedonism, destination experience, and tourism innovativeness and explains $80.9 \%$ of tourist behavioral intention. These findings accomplish the primary goal of the study, in terms of extending the model of goal-directed behavior (MGB) for tourism studies.

Second, previous literature has already acknowledged the importance of hedonic experience on tourist behavior (Grappi \& Montanari, 2011; Huang et al., 2013). This study advances this idea by conceptualizing three elements of hedonism, meaning enjoyment, positive emotions, and emotional involvement, in the context of amusement park visitors. Findings indicate that hedonism, in general, has a strong influence on tourists' desire. In addition to the past research on positive emotions (e.g., Grappi \& Montanari, 2011; Perugini \& Bagozzi, 2001), we show that hedonism plays a crucial role in mediating the emotional path in the decision-making process of tourists. We contend that this might be especially true in the context of amusement parks.

Third, another theoretical implication of this study is that results provide meaningful insights into the destination experience as a predictor of behavioral intention. In particular, this research contributes to destination experience literature reflecting on a specific type of tourism attraction (i.e., amusement parks) applying the concept of destination experience to a broader framework (MGB), rather than a specific brand, product or service (e.g., Brakus et al., 2009; Zarantonello \& Schmitt, 2010). Although recent studies brought the 
concept of destination experience to the tourism literature (Barnes et al., 2014), our results provide an improved framework to understand its effects on tourists' desire and behavioral intention, focusing on a specific type of entertainment service such as amusement parks. This study provides a more robust framework in analyzing destination experience by presenting a comparison of effects with other important tourism-related variables (emotional elements, hedonism, innovativeness). The findings also extend previous research by revealing that not all destination experience dimensions (sensory, affective, behavioral, and intellectual) equally influence tourist behavioral intention. Indeed, only sensory and intellectual destination experiences were found to affect behavioral intention. However, it is important to note that, conversely to previous research (e.g., Brakus et al., 2009; Zarantonello \& Schmitt, 2010), affective and behavioral experiences do not affect tourists' behavioral intentions.

Finally, the fourth contribution of this study is that tourism innovativeness indeed exerts a significant influence on tourists' desire. Our findings extend the previous research (Couture et al.. 2015) on the role of innovativeness as a predictor of tourist behavior. Since innovativeness was mostly examined in the studies of other areas than tourism, this research sheds light on the influence of innovativeness over the tourists' decision-making process. Findings suggest that highly innovative tourist attractions would have more desire when compared to non-innovative ones. 
Besides its significant theoretical contributions, this study also reveals practical implications for tourism practitioners and destination experience managers. Findings first confirm that desire is the most important factor which induces tourists to decide about their future travel plans. Managers should focus on effective global advertisements or online social media to inspire the consumers' desire to visit experiential tourist attractions while traveling, especially in the context of amusement parks. Managing the customer experience and making it a hedonically valuable experience is another key factor in which managers should concentrate. They can take advantage of our research findings, considering the positive impact of hedonism on forming the desire to visit experiential tourist attractions, such as amusement parks. Specifically, positive emotions and hedonism should be considered as a focal point for attracting tourists to the proposed park or attraction. For example, marketers of experiential tourist attractions should include these positive emotions and sensorial factors of the park in their global advertising campaigns using emotional videos or posters. Most of the studies examining tourist behavior and satisfaction also suggest that it is important to shape experiences in a way that they will meet, or exceed, the emotional expectations of tourists (e.g., Bigne et al., 2005; Hosany \& Gilbert, 2009).

The findings of this study also indicate that managers should carefully build the destination experience by considering the significance of sensorial and intellectual experiences. This effect can be achieved by including unique features and services that will change tourist preferences on visiting other entertainment facilities. Regarding brand building, Beckman et al. (2013) suggested designing elements in a way that will allow visitors to feel the five 
senses from a destination: sight, sound, touch, smell, and taste. Managers should combine all the senses in the tourist attraction features and try to pursue this in their marketing campaigns.

Furthermore, managers should also design the experiential tourist attractions in a way that they will give an extraordinary experience with innovative attractions to stimulate tourists' desire and behavioral intentions. Innovativeness of a tourist should indeed be considered by tourism managers as an important factor in desire. Researchers also mentioned that highly innovative tourists would be more interested in experiencing new technologies. For instance, Jung et al. (2015) suggested that augmented reality recently became the main trend in the experiential tourist attractions industry and it should not be neglected while building or reshaping experiential tourist attractions. Furthermore, Ozturk et al. (2016) mentioned that the Marriot hotels chain created an application that allows users to visit different cities, get Marriot points and use them in the hotel of the same chain. It is assumed that this kind of gamification can also lead innovative consumers to visit experiential tourist attractions.

Limitations and Future Research

Although this research provides significant contributions to tourism management, particularly to the amusement park industry, some limitations should be addressed in future studies. 
First, an important part of our sample was composed of undergraduate and post-graduate students; this factor being an important limitation of this study. Such a prominence of students and lower age range in our sample may have a direct impact on tourist desire and innovativeness for this specific tourist attraction. In this context, it would be particularly interesting to examine the model with different age groups and compare the opinions of each generation.

Second, the survey was administered through social networking websites (e.g., Facebook, Messenger), which might limit the type of participant related to interests, reducing the likelihood of obtaining a population representation. Although measures to increase external generalizability of results were taken, future research is needed to conduct a field survey with a broader audience (more balanced in terms of education and age) and the use of other types of data collection methods (beyond university students and online panels). Future research could also investigate the extended MGB model with a sample that represents different cultures across the globe, especially American and Asian tourists, as these continents are leading the growth of the amusement park industry.

Finally, the context of amusement parks could also be a limitation since it could have a direct impact on our research variables (e.g., innovativeness and desire). For instance, the experience and the emotions felt in an amusement park can have more impact on tourist desire (especially for young tourists) than visiting other attractions such as a museum or a historical site. Thus, future research should also explore our extended MGB model in other specific tourist attractions than amusement parks. This could be crucial to understand the nonsignificant impacts of affective and behavioral destination experiences better 
since these effects could be specific to this type of tourist experience and might be relevant to other types of tourism.

\section{CONCLUSION}

This research extends previous findings uncovering an important underlying emotional path of the model of goal-directed behavior including new experience-related variables (hedonism, destination experience, tourism innovativeness). This study extends the model of goal-directed behavior (MGB) to contribute to the existing literature gap, offering a conceptual framework that sheds light on the impact of hedonism, destination experience, and tourism innovativeness on tourists' desire and behavioral intention. The research findings illustrated three main conclusions. First, hedonism, experience, and tourism innovativeness are important predictors of tourist behavioral intention. Second, findings support the mediating role of hedonism on the emotional path: emotions $\rightarrow$ hedonism $\rightarrow$ desire $\rightarrow$ behavioral intention. Finally, our findings have implications for tourism managers crafting destination experiences by providing emotional, experiential, and innovative tourist attractions and offers theoretical contributions for tourism research by presenting a new framework to predict behavioral intentions of tourists. 


\section{REFERENCES}

Agarwal, R., \& Prasad, J. (1998). A Conceptual and Operational Definition of Personal Innovativeness in the Domain of Information Technology. Information Systems Research, 9(2), 204-215. doi:10.1287/isre.9.2.204

Ajzen, I. (1985). From Intentions to Actions: A Theory of Planned Behavior. In J. Kuhl \& J. Beckmann (Eds.), Action Control (pp. 11-39). Berlin H: Springer-Verlag. doi:10.1007/978-3-642-69746-3_2

Babin, B. J., Darden, W. R., \& Griffin, M. (1994). Work and/or Fun: Measuring Hedonic and Utilitarian Shopping Value. Journal of Consumer Research, 20(4), 644-656. doi:10.1086/209376

Babin, B. J., Lee, Y., Kim, E., \& Griffin, M. (2005). Modeling consumer satisfaction and word-of-mouth: restaurant patronage in Korea. Journal of Services Marketing, 19(3), 133-139. doi:10.1108/08876040510596803

Bagozzi, R. P. (1992). The Self-Regulation of Attitudes, Intentions, and Behavior. Social Psychology Quarterly, 55(2), 178-204. doi:10.2307/2786945

Barnes, S. J., Mattsson, J., \& Sørensen, F. (2014). Destination experience and visitor behavior: Testing a scale in the tourism context. Annals of Tourism Research, 48, 121-139. doi:10.1016/j.annals.2014.06.002

Bartels, J., \& Reinders, M. J. (2011). Consumer innovativeness and its correlates: A propositional inventory for future research. Journal of Business Research, 64(6), 601-609. doi:10.1016/j.jbusres.2010.05.002 
Beckman, E., Kumar, A., \& Kim, Y. (2013). The Impact of Experience on Downtown Success. Journal of Travel Research, 52(5), 646-658. doi:10.1177/0047287513478502

Bigné, J. E., Andreu, L., \& Gnoth, J. (2005). The theme park experience: An analysis of pleasure, arousal and satisfaction. Tourism Management, 26(6), 833-844. doi:10.1016/j.tourman.2004.05.006

Brakus, J. J., Schmitt, B. H., \& Zarantonello, L. (2009). Experience: What Is It? How Is It Measured? Does It Affect Loyalty? Journal of Marketing, 73(3), 52-68. doi:10.1509/jmkg.73.3.52

Britto, F., De Azavedo Maia, \& Alencar, S., De Farias. (2013). Riesgos ¿qué riesgos?: Estrategias de reducción de riesgos y participación emocional de consumidores de turismo aventura. Estudios y perspectivas en turismo, 22(1), 65-83. Retrieved from http://www.scielo.org.ar/

Brochado, A., Rita, P., \& Gameiro, C. (2015). Exploring backpackers' perceptions of the hostel service quality. International Journal of Contemporary Hospitality Management, 27(8), 1839-1855.

Chen, L., Scott, N., \& Benckendorff, P. (2017). Mindful tourist experiences: A Buddhist perspective. Annals of Tourism Research, 64, 1-12. https://doi.org/10.1016/j.annals.2017.01.013

Childers, T. L., Carr, C. L., Peck, J., \& Carson, S. (2001). Hedonic and utilitarian motivations for online retail shopping behavior. Journal of Retailing, 77(4), 511-535. doi:10.1016/s0022-4359(01)00056-2 
Chin, W. W. (1998). The Partial Least Squares Approach to Structural Equation Modeling. Modern methods for business research, 295(2), 295-336. Retrieved from www.researchgate.net

Choi, Y., \& Park, J. (2017). The decision-making processes of duty-free shop users using a goal-directed behavior model: The moderating effect of gender. Journal of Hospitality and Tourism Management, 31, 152-162. doi:10.1016/j.jhtm.2016.11.001

Cornelis, P. C. (2010). Impact of new attractions on theme park attendance. Worldwide Hospitality and Tourism Themes, 2(3), 262-280. doi:10.1108/17554211011052203

Couture, A., Arcand, M., Sénécal, S., \& Ouellet, J. (2015). The Influence of Tourism Innovativeness on Online Consumer Behavior. Journal of Travel Research, 54(1), 66-79. doi:10.1177/0047287513513159

Davis, F. D., Bagozzi, R., \& Warshaw, P. R. (1992). Extrinsic and Intrinsic Motivation to Use Computers in the Workplace. Journal of Applied Social Psychology, 22(14), 1111-1132. doi:10.1111/j.1559-1816.1992.tb00945.x

Editorial. (2006). Hershey Park introduces peanut butter ride. Attraction management, 11(2), 13. Retrieved from http://www.attractionsmanagement.com/

Flynn, L. R., \& Goldsmith, R. E. (1993). A Validation of the Goldsmith and Hofacker Innovativeness scale. Educational and Psychological Measurement, 53(4), 1105-1116. doi:10.1177/0013164493053004023 
Forbes (2019). Megatrends of the Tourism and Travel Industry. Retrieved from https://www.forbes.com/sites/jeffromm/2019/03/28/megatrends-of-thetourism-and-travel-industry/

Formica, S., \& Olsen, M. D. (1998). Trends in the amusement park industry. International Journal of Contemporary Hospitality Management, 10(7), 297-308. doi:10.1108/09596119810240933

Fornell, C., \& Larcker, D. F. (1981). Evaluating Structural Equation Models with Unobservable Variables and Measurement Error. Journal of Marketing Research, 18(1), 39-50. doi:10.2307/3151312

Ganglmair-Wooliscroft, A., \& Wooliscroft, B. (2016). Diffusion of innovation: The case of ethical tourism behavior. Journal of Business Research, 69(8), 2711-2720. doi:10.1016/j.jbusres.2015.11.006

Gilbert, D. T., \& Wilson, T. D. (2007). Prospection: Experiencing the Future. Science, 317(5843), 1351-1354. doi: 10.1126/science.1144161

Gnoth, J. (1997). Tourism motivation and expectation formation. Annals of Tourism Research, 24(2), 283-304. doi:10.1016/s0160-7383(97)80002-3

Goldsmith, R. E., \& Hofacker, C. F. (1991). Measuring Consumer Innovativeness. Journal of the Academy of Marketing Science, 19(3), 209-221. doi:10.1007/BF02726497

Goldsmith, R. E., \& Litvin, S. W. (1999). Heavy Users of Travel Agents: A Segmentation Analysis of Vacation Travelers. Journal of Travel Research, 38(2), 127-133. doi:10.1177/004728759903800205

Götz, O., Liehr-Gobbers, K., \& Kraftt, M. (2010). Evaluation of structural equation models using the partial least squares (PLS) approach. In V. E. 
Vinzi, W. W. Chin, J. Henseler, \& H. Wang (Eds.), Handbook of Partial Least Squares (pp. 691-711). Berlin: Springer. doi:10.1007/978-3-54032827-8_30

Grappi, S., \& Montanari, F. (2011). The role of social identification and hedonism in affecting tourist re-patronizing behaviors: The case of an Italian festival. Tourism Management, 32(5), 1128-1140. doi:10.1016/j.tourman.2010.10.001

Gunn, C. A. (1994). Tourism planning: basics, concepts, cases (3rd ed., Vol. 32). Washington D.C: Taylor \& Francis.

Guo, Y., \& Barnes, S. (2011). Purchase behavior in virtual worlds: An empirical investigation in Second Life. Information \& Management, 48(7), 303-312. doi:10.1016/j.im.2011.07.004

Gursoy, D., Spangenberg, E. R., \& Rutherford, D. G. (2006). The hedonic and utilitarian dimensions of attendees' attitudes toward festivals. Journal of Hospitality \& Tourism Research, 30(3), 279-294. doi: $10.1177 / 1096348006287162$

Hair, J. F., Black, W. C., Babin, B. J., \& Anderson, R. E. (2010). Multivariate Data Analysis (7th ed.). Harlow: Pearson Education Limited.

Han, H., \& Ryu, K. (2009). The Roles of the Physical Environment, Price Perception, and Customer Satisfaction in Determining Customer Loyalty in the Restaurant Industry. Journal of Hospitality \& Tourism Research, 33(4), 487-510. doi:10.1177/1096348009344212

Han, H., \& Ryu, K. (2012). The Theory of Repurchase Decision-Making (TRD): Identifying the Critical Factors in the Post-Purchase Decision-Making 
Process. International Journal of Hospitality Management, 31(3), 786797. doi:10.1016/j.jhm.2011.09.015

Han, H., Back, K., \& Barrett, B. (2010). A consumption emotion measurement development: a full-service restaurant setting. The Service Industries Journal, 30(2), 299-320. doi:10.1080/02642060802123400

Harvard Business Review (2015). The Real Guide to Innovation in Tourism. Retrieved from https://hbr.org/2015/07/the-real-guide-to-innovationtourism

Henseler, J., Hubona, G., \& Ray, P. A. (2016). Using PLS path modeling in new technology research: updated guidelines. Industrial Management \& Data Systems, 116(1), 2-20. doi:10.1108/imds-09-2015-0382

Henseler, J., Ringle, C. M., \& Sarstedt, M. (2015). A new criterion for assessing discriminant validity in variance-based structural equation modeling. Journal of the Academy of Marketing Science,43(1), 115-135. doi:10.1007/s11747-014-0403-8

Henseler, J., Ringle, C. M., \& Sinkovics, R. R. (2009). The use of partial least squares path modeling in international marketing. Advances in international marketing, 20, 277-319. doi:10.1108/S14747979(2009)0000020014

Hirschman, E. C. (1980). Black ethnicity and innovative communication. Journal of the Academy of Marketing Science, 8(1-2), 100-119. doi:10.1007/bf02721977 
Hirschman, E. C., \& Holbrook, M. B. (1982). Hedonic Consumption: Emerging Concepts, Methods and Propositions. Journal of Marketing, 46(3), 92. doi:10.2307/1251707

Hoffmann, S., \& Soyez, K. (2010). A cognitive model to predict domain-specific consumer innovativeness. Journal of Business Research, 63(7), 778785. doi:10.1016/j.jbusres.2009.06.007

Holbrook, M. B. (1980). Some Preliminary Notes on Research in Consumer Esthetics. Advances In Consumer Research,7(1). Retrieved from http://www.acrwebsite.org/

Holsapple, C. W., \& Wu, J. (2007). User acceptance of virtual worlds. ACM SIGMIS Database, 38(4), 86. doi:10.1145/1314234.1314250

Horng, J., Liu, C., Chou, H., \& Tsai, C. (2012). Understanding the impact of culinary brand equity and destination familiarity on travel intentions. Tourism Management, 33(4), 815-824. doi:10.1016/j.tourman.2011.09.004

Hosany, S., \& Gilbert, D. (2009). Measuring Tourists' Emotional Experiences toward Hedonic Holiday Destinations. Journal of Travel Research, 49(4), 513-526. doi:10.1177/0047287509349267

Huang, Y., Backman, S. J., Backman, K. F., \& Moore, D. (2013). Exploring user acceptance of 3D virtual worlds in travel and tourism marketing. Tourism Management, 36, 490-501. doi:10.1016/j.tourman.2012.09.009

Hurt, H. T., Joseph, K., \& Cook, C. D. (1977). Scales for the measurement of innovativeness. Human Communication Research, 4(1), 58-65. doi:10.1111/j.1468-2958.1977.tb00597.x 
Ingram, C.; Caruana, R., \& McCabe, Scott. (2017). PARTicipative inquiry for tourist experience. Annals of Tourism Research, 65, 13-24. https://doi.org/10.1016/j.annals.2017.04.008.

Io, M. (2016). Exploring the impact of hedonic activities on casino-hotel visitors positive emotions and satisfaction. Journal of Hospitality and Tourism Management, 26, 27-35. doi:10.1016/j.jhtm.2015.07.004

Jung, T., Chung, N., \& Leue, M. C. (2015). The determinants of recommendations to use augmented reality technologies: The case of a Korean theme park. Tourism Management, 49, 75-86. doi:10.1016/j.tourman.2015.02.013

Khan, I., \& Rahman, Z. (2015). Experience anatomy in retailing: An interpretive structural modeling approach. Journal of Retailing and Consumer Services, 24, 60-69. doi:10.1016/j.jretconser.2015.02.003

Kim, S. (2011). Audience involvement and film tourism experiences: Emotional places, emotional experiences. Tourism Management, 33(2), 387-396. doi:10.1016/j.tourman.2011.04.008

Kim, E., Tang, L., \& Bosselman, R. (2019). Customer Perceptions of Innovativeness: An Accelerator for Value Co-Creation. Journal of Hospitality \& Tourism Research, 43(6): 807-838. doi:10.1177/1096348019836273

Kirton, M. (1976). Adaptors and innovators: A description and measure. Journal of Applied Psychology, 61(5), 622-629. doi:10.1037//0021-9010.61.5.622 
Kivela, J., \& Crotts, J. C. (2006). Tourism and gastronomy: Gastronomy's influence on how tourists experience a destination. Journal of Hospitality \& Tourism Research, 30(3), 354-377. doi: 10.1177/1096348006286797

Kwortnik, R. J., \& Ross, W. T. (2007). The role of positive emotions in experiential decisions. International Journal of Research in Marketing, 24(4), 324-335. doi:10.1016/j.jiresmar.2007.09.002

Lee, J., \& Back, K. (2008). Attendee-based brand equity. Tourism Management, 29(2), 331-344. doi:10.1016/j.tourman.2007.03.002

Lee, C., Song, H., Bendle, L. J., Kim, M., \& Han, H. (2012). The impact of nonpharmaceutical interventions for $2009 \mathrm{H} 1 \mathrm{~N} 1$ influenza on travel intentions: A model of goal-directed behavior. Tourism Management, 33(1), 89-99. doi:10.1016/j.tourman.2011.02.006

Li, L., \& Buhalis, D. (2006). E-Commerce in China: The case of travel. International Journal of Information Management, 26(2), 153-166. doi:10.1016/j.ijinfomgt.2005.11.007

Malone, S., Mccabe, S., \& Smith, A. P. (2014). The role of hedonism in ethical tourism. Annals of Tourism Research, 44, 241-254. doi:10.1016/j.annals.2013.10.005

Meng, B., \& Choi, K. (2016). The role of authenticity in forming slow tourists intentions: Developing an extended model of goal-directed behavior. Tourism Management, 57, 397-410. doi:10.1016/j.tourman.2016.07.003

Milman, A. (2008). Theme park tourism and management strategy. In A. G. Woodside \& D. Martin (Eds.), Tourism management: analysis, behavior 
and strategy (pp. 218-231). Wallingford: CABI.

doi:10.1079/9781845933234.0218

Moreira, A. C., Fortes, N., \& Santiago, R. (2017). Influence of sensory stimuli on experience, brand equity and purchase intention. Journal of Business Economics and Management, 18(1), 68-83. doi:10.3846/16111699.2016.1252793

Oliveira, C., Brochado, A., Moro, S., \& Rita, P. (2019). Consumer perception of tourist experience through online reviews. Worldwide Hospitality and Tourism Themes. 11 (6): 696-717.

Ozturk, A. B., Nusair, K., Okumus, F., \& Hua, N. (2016). The role of utilitarian and hedonic values on users' continued usage intention in a mobile hotel booking environment. International Journal of Hospitality Management, 57, 106-115. doi:10.1016/j.ijhm.2016.06.007

Page, S. (2003). Tourism management: Managing for change. UK: Butterworth Heinemann.

Park, E., Lee, S., \& Peters, D. J. (2017). lowa wetlands outdoor recreation visitors' decision-making process: An extended model of goal-directed behavior. Journal of Outdoor Recreation and Tourism, 17, 64-76. doi:10.1016/j.jort.2017.01.001

Pearce, P. L. (1988). The Ulysses factor: evaluating visitors in tourist settings. New York: Springer-Verlag.

Pereira, H. G., de Fátima Salgueiro, M., \& Rita, P. (2016). Online purchase determinants of loyalty: The mediating effect of satisfaction in 
tourism. Journal of Retailing and consumer Services, 30, 279-291. doi:10.1016/i.jretconser.2016.01.003

Perugini, M., \& Bagozzi, R. P. (2001). The role of desires and anticipated emotions in goal-directed behaviors: Broadening and deepening the theory of planned behavior. British Journal of Social Psychology, 40(1), 79-98. doi:10.1348/014466601164704

Pikkemaat, B., \& Schuckert, M. (2007). Success factors of theme parks - An exploratory study.Preliminary Communication, 55(2), 197-208. Retrieved from http://hrcak.srce.hr/

Poels, K., \& Dewitte, S. (2008). Hope and self-regulatory applied to an advertising context - Promoting prevention stimulates goal-directed behavior. Journal of Business Research, 61(10), 1030-1040. doi:10.1016/j.jbusres.2007.09.019

Ragheb, M. G. (1996). The search for meaning in leisure pursuits: review, conceptualization and a need for a psychometric development. Leisure Studies, 15(4), 245-258. doi:10.1080/026143696375549

Raju, P. S. (1980). Optimum Stimulation Level: Its Relationship to Personality, Demographics, and Exploratory Behavior. Journal of Consumer Research, 7(3), 272-282. doi:10.1086/208815

Ringle, C. M., Sarstedt, M., \& Schlittgen, R. (2014). Genetic algorithm segmentation in partial least squares structural equation modeling. $O R$ Spectrum, 36(1), 251-276. doi:10.1007/s00291-013-0320-0 
Rita, P., Oliveira, T., Estorninho, A., \& Moro, S. (2018). Mobile services adoption in a hospitality consumer context. International Journal of Culture, Tourism and Hospitality Research, 12(1), 143-158.

Roehrich, G. (1994). Innovativité hédoniste et sociale: proposition d'une échelle de mesure. Recherche et Applications en Marketing, 9(2), 19-42. doi:10.1177/076737019400900202

Roehrich, G. (2004). Consumer innovativeness Concepts and measurements. Journal of Business Research, 57(6), 671-677. doi:10.1016/S0148-2963(02)00311-9

Salazar, A., Costa, J., \& Rita, P. (2010). A service quality evaluation scale for the hospitality sector: Dimensions, attributes and behavioural intentions. Worldwide Hospitality and Tourism Themes, 2(4), 383-397.

Schmitt, B., Brakus, J. J., \& Zarantonello, L. (2015). From experiential psychology to consumer experience. Journal of Consumer Psychology, 25(1), 166-171. doi:10.1016/j.jcps.2014.09.001

Shen, J., \& Eder, L. (2009). Determining Factors in the Acceptance of Social Shopping Websites. In AMCIS 2009 Proceedings, 290. Retrieved from http://aisel.aisnet.org/

Song, H. J., Lee, C., Kang, S. K., \& Boo, S. (2012). The effect of environmentally friendly perceptions on festival visitors' decision-making process using an extended model of goal-directed behavior. Tourism Management, 33(6), 1417-1428. doi:10.1016/j.tourman.2012.01.004

Song, H., You, G., Reisinger, Y., Lee, C., \& Lee, S. (2014). Behavioral Intention of Visitors to an Oriental Medicine Festival: An Extended Model of Goal- 
Directed Behavior. Tourism Management, 42, 101-113. doi:doi.org/10.1016/j.tourman.2013.11.003

Strzelecka, M., Nisbett, G. S., \& Woosnam, K. M. (2017). The hedonic nature of conservation volunteer travel. Tourism Management, 63, 417-425. doi:10.1016/j.tourman.2017.06.022

Stylos, N., Vassiliadis, C. A., Bellou, V., \& Andronikidis, A. (2016). Destination images, holistic images and personal normative beliefs: Predictors of behavioral intention a destination. Tourism Management, 53, 40-60. doi:10.1016/j.tourman.2015.09.006

Taylor, S. A. (2007). The addition of anticipated regret to attitudinally based, goal-directed models of information search behaviors under conditions of uncertainty and risk. British Journal of Social Psychology, 46(4), 739-768. doi:10.1348/014466607x174194

Taylor, S. A., Ishida, C., \& Wallace, D. W. (2009). Intention to Engage in Digital Piracy. Journal of Service Research, 11(3), 246-262. doi:10.1177/1094670508328924

UNWTO. (2019). Tourism Highlights. doi: 10.18111/9789284421152

Wearing, S. \& Foley, C. (2017). Understanding the tourist experience of cities. Annals of Tourism Research, 65, 97-107. https://doi.org/10.1016/j.annals.2017.05.007.

Williams, S. (1998). Tourism Geography. London: Routledge.

Wylson, A., \& Wylson, P. (1994). Theme parks, leisure centres, zoos and aquaria. London: Longman. 
Yi, M. Y., \& Hwang, Y. (2003). Predicting the use of web-based information systems: self-efficacy, enjoyment, learning goal orientation, and the technology acceptance model. International Journal of Human-Computer Studies, 59(4), 431-449. doi:10.1016/s1071-5819(03)00114-9

Zaichkowsky, J. L. (1985). Measuring the Involvement Construct. Journal of Consumer Research, 12(3), 341. doi:10.1086/208520

Zarantonello, L., \& Schmitt, B. H. (2010). Using the experience scale to profile consumers and predict consumer behavior. Journal of Brand Management, 17(7), 532-540. doi:10.1057/bm.2010.4

Zins, A. H. (2002). Consumption Emotions, Experience Quality and Satisfaction. Journal of Travel \& Tourism Marketing, 12(2-3), 3-18. doi:10.1300/j073v12n02_02 


\section{APPENDICES}

Appendix 1 - Cross Loadings table

\begin{tabular}{|c|c|c|c|c|c|c|c|c|c|c|c|}
\hline Items & $\mathrm{AE}$ & BE & DE & EI & EN & HE & $\mathrm{TI}$ & IE & IR & PE & SE \\
\hline AE1 & 0.79 & 0.40 & 0.33 & 0.40 & 0.41 & 0.37 & 0.29 & 0.28 & 0.30 & 0.43 & 0.46 \\
\hline AE2 & 0.77 & 0.40 & 0.46 & 0.30 & 0.38 & 0.48 & 0.30 & 0.23 & 0.41 & 0.39 & 0.53 \\
\hline AE3 & 0.81 & 0.39 & 0.39 & 0.35 & 0.28 & 0.36 & 0.36 & 0.34 & 0.35 & 0.33 & 0.41 \\
\hline BE1 & 0.41 & 0.86 & 0.51 & 0.46 & 0.52 & 0.52 & 0.43 & 0.28 & 0.41 & 0.59 & 0.48 \\
\hline BE2 & 0.47 & 0.86 & 0.33 & 0.44 & 0.40 & 0.40 & 0.35 & 0.16 & 0.27 & 0.42 & 0.46 \\
\hline BE3 & 0.26 & 0.58 & 0.19 & 0.13 & 0.23 & 0.23 & 0.10 & 0.01 & 0.14 & 0.20 & 0.30 \\
\hline DE1 & 0.49 & 0.43 & 0.94 & 0.51 & 0.54 & 0.66 & 0.62 & 0.34 & 0.86 & 0.57 & 0.53 \\
\hline DE2 & 0.47 & 0.40 & 0.95 & 0.50 & 0.50 & 0.58 & 0.61 & 0.38 & 0.85 & 0.53 & 0.48 \\
\hline DE3 & 0.45 & 0.37 & 0.93 & 0.48 & 0.47 & 0.58 & 0.63 & 0.35 & 0.85 & 0.51 & 0.42 \\
\hline DE4 & 0.39 & 0.47 & 0.75 & 0.47 & 0.46 & 0.63 & 0.53 & 0.25 & 0.56 & 0.52 & 0.43 \\
\hline El1 & 0.39 & 0.42 & 0.44 & 0.84 & 0.46 & 0.46 & 0.41 & 0.22 & 0.39 & 0.49 & 0.43 \\
\hline El2 & 0.40 & 0.40 & 0.49 & 0.92 & 0.47 & 0.48 & 0.48 & 0.36 & 0.45 & 0.53 & 0.47 \\
\hline El3 & 0.40 & 0.44 & 0.52 & 0.92 & 0.49 & 0.51 & 0.45 & 0.37 & 0.48 & 0.53 & 0.45 \\
\hline EN1 & 0.43 & 0.49 & 0.54 & 0.49 & 0.93 & 0.68 & 0.48 & 0.33 & 0.46 & 0.77 & 0.57 \\
\hline EN2 & 0.36 & 0.45 & 0.44 & 0.44 & 0.91 & 0.57 & 0.40 & 0.27 & 0.35 & 0.70 & 0.51 \\
\hline EN3 & 0.44 & 0.43 & 0.54 & 0.54 & 0.85 & 0.60 & 0.47 & 0.33 & 0.44 & 0.70 & 0.51 \\
\hline EN4 & 0.40 & 0.47 & 0.46 & 0.46 & 0.93 & 0.68 & 0.41 & 0.28 & 0.40 & 0.78 & 0.55 \\
\hline HE1 & 0.43 & 0.48 & 0.61 & 0.46 & 0.70 & 0.86 & 0.52 & 0.27 & 0.49 & 0.74 & 0.53 \\
\hline HE2 & 0.38 & 0.33 & 0.61 & 0.47 & 0.50 & 0.80 & 0.53 & 0.28 & 0.53 & 0.50 & 0.40 \\
\hline HE3 & 0.42 & 0.43 & 0.45 & 0.42 & 0.52 & 0.83 & 0.46 & 0.20 & 0.45 & 0.61 & 0.40 \\
\hline HE4 & 0.49 & 0.49 & 0.59 & 0.49 & 0.62 & 0.89 & 0.56 & 0.34 & 0.54 & 0.72 & 0.57 \\
\hline Tl1 & 0.46 & 0.45 & 0.69 & 0.54 & 0.54 & 0.66 & 0.82 & 0.36 & 0.63 & 0.60 & 0.51 \\
\hline TI2 & 0.31 & 0.33 & 0.54 & 0.38 & 0.38 & 0.48 & 0.86 & 0.32 & 0.55 & 0.46 & 0.35 \\
\hline TI3 & 0.34 & 0.34 & 0.54 & 0.35 & 0.40 & 0.50 & 0.89 & 0.26 & 0.51 & 0.45 & 0.34 \\
\hline TI4 & 0.33 & 0.32 & 0.49 & 0.30 & 0.35 & 0.50 & 0.71 & 0.21 & 0.40 & 0.44 & 0.31 \\
\hline TI5 & 0.25 & 0.27 & 0.51 & 0.42 & 0.37 & 0.43 & 0.84 & 0.26 & 0.51 & 0.39 & 0.25 \\
\hline TI6 & 0.23 & 0.26 & 0.46 & 0.44 & 0.32 & 0.41 & 0.81 & 0.27 & 0.48 & 0.37 & 0.20 \\
\hline IE1 & 0.23 & 0.08 & 0.19 & 0.30 & 0.21 & 0.18 & 0.23 & 0.76 & 0.22 & 0.24 & 0.17 \\
\hline IE2 & 0.22 & 0.08 & 0.15 & 0.11 & 0.11 & 0.12 & 0.08 & 0.67 & 0.18 & 0.10 & 0.09 \\
\hline IE3 & 0.34 & 0.27 & 0.42 & 0.36 & 0.37 & 0.37 & 0.40 & 0.86 & 0.43 & 0.38 & 0.35 \\
\hline Bl1 & 0.39 & 0.36 & 0.80 & 0.48 & 0.46 & 0.58 & 0.57 & 0.32 & 0.89 & 0.52 & 0.46 \\
\hline BI2 & 0.45 & 0.35 & 0.85 & 0.47 & 0.43 & 0.55 & 0.60 & 0.38 & 0.96 & 0.48 & 0.47 \\
\hline BI3 & 0.41 & 0.31 & 0.79 & 0.43 & 0.38 & 0.52 & 0.59 & 0.40 & 0.94 & 0.45 & 0.42 \\
\hline PE1 & 0.38 & 0.48 & 0.48 & 0.44 & 0.73 & 0.65 & 0.47 & 0.24 & 0.39 & 0.80 & 0.54 \\
\hline PE2 & 0.33 & 0.35 & 0.49 & 0.47 & 0.69 & 0.59 & 0.47 & 0.28 & 0.43 & 0.80 & 0.46 \\
\hline PE3 & 0.41 & 0.42 & 0.45 & 0.45 & 0.67 & 0.58 & 0.37 & 0.27 & 0.39 & 0.82 & 0.52 \\
\hline PE4 & 0.38 & 0.47 & 0.48 & 0.48 & 0.74 & 0.68 & 0.45 & 0.25 & 0.41 & 0.86 & 0.52 \\
\hline PE5 & 0.40 & 0.38 & 0.42 & 0.46 & 0.48 & 0.46 & 0.48 & 0.41 & 0.43 & 0.63 & 0.37 \\
\hline PE6 & 0.35 & 0.47 & 0.43 & 0.41 & 0.58 & 0.61 & 0.41 & 0.23 & 0.34 & 0.77 & 0.46 \\
\hline PE7 & 0.45 & 0.45 & 0.53 & 0.50 & 0.61 & 0.65 & 0.47 & 0.30 & 0.52 & 0.82 & 0.56 \\
\hline SE1 & 0.53 & 0.41 & 0.39 & 0.41 & 0.43 & 0.44 & 0.31 & 0.26 & 0.41 & 0.47 & 0.85 \\
\hline SE2 & 0.49 & 0.51 & 0.47 & 0.53 & 0.58 & 0.54 & 0.42 & 0.32 & 0.43 & 0.63 & 0.89 \\
\hline SE3 & 0.47 & 0.43 & 0.44 & 0.32 & 0.47 & 0.47 & 0.29 & 0.16 & 0.39 & 0.46 & 0.78 \\
\hline
\end{tabular}

Notes: AE - Affective Experience; BE - Behavioral Experience; DE - Desire; El - Emotional Involvement; EN - Enjoyment; HE - Hedonism; TI - Tourism Innovativeness; IE - Intellectual Experience; $\mathrm{BI}$ - Behavioral Intention; PE - Positive Emotions; SE - Sensorial Experience 


\section{FIGURES AND TABLES}

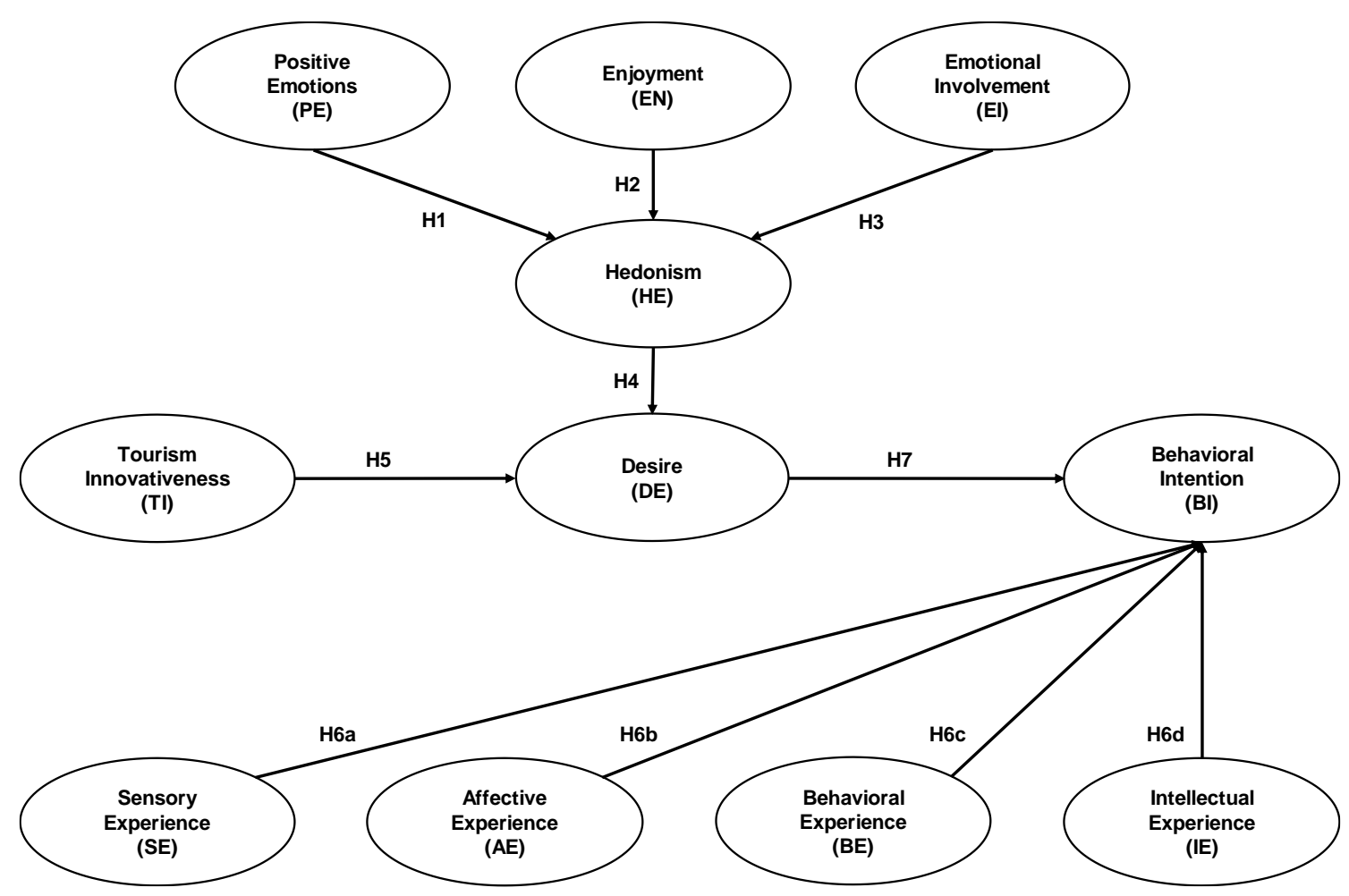

Figure 1: Conceptual model and research hypotheses 


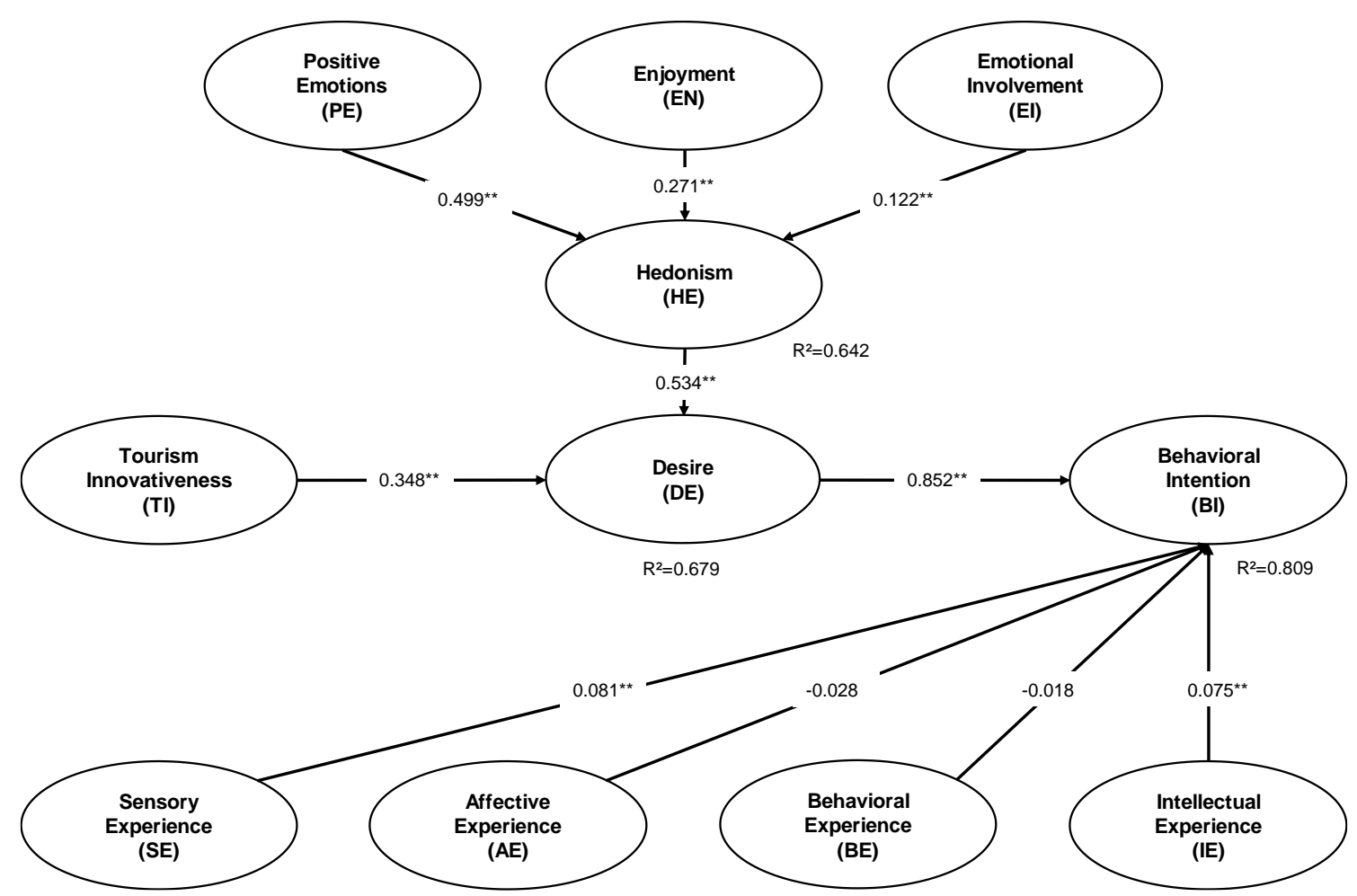

Figure 2: Structural model with path coefficients and $r$-squares (Note: ${ }^{*} \mathrm{p}<0.05 ;{ }^{* *} \mathrm{p}<0.01$ ) 


\begin{tabular}{|c|c|c|c|}
\hline Construct & Items & Questions & Reference \\
\hline \multirow{4}{*}{ Enjoyment } & EN1 & I enjoy experiencing Amusement park very much & \multirow{4}{*}{$\begin{array}{l}\text { Huang et al. } \\
(2013)\end{array}$} \\
\hline & EN2 & I think experiencing Amusement park is quite enjoyable & \\
\hline & EN3 & $\begin{array}{l}\text { I would describe experiencing Amusement park as very } \\
\text { interesting }\end{array}$ & \\
\hline & EN4 & Experience in Amusement park is fun & \\
\hline \multirow{7}{*}{ Positive Emotions } & PE1 & Amusement & \multirow{7}{*}{$\begin{array}{l}\text { Huang et al. } \\
(2013)\end{array}$} \\
\hline & PE2 & Interest & \\
\hline & PE3 & Contentment & \\
\hline & PE4 & Joy & \\
\hline & PE5 & Pride & \\
\hline & PE6 & Cheerfulness & \\
\hline & PE7 & Delight & \\
\hline \multirow{3}{*}{$\begin{array}{l}\text { Emotional } \\
\text { Involvement }\end{array}$} & El1 & $\begin{array}{l}\text { When I visit an Amusement park, I feel carried off by the } \\
\text { environment }\end{array}$ & \multirow{3}{*}{$\begin{array}{l}\text { Huang et al. } \\
(2013)\end{array}$} \\
\hline & $\mathrm{El} 2$ & $\begin{array}{l}\text { When I visit an Amusement park, I feel as if I am part of the } \\
\text { entire environment }\end{array}$ & \\
\hline & EI3 & $\begin{array}{l}\text { When I visit an Amusement park, I feel deeply about the } \\
\text { environment }\end{array}$ & \\
\hline \multirow{4}{*}{ Hedonism } & HE1 & The experience in Amusement park is truly enjoyable & \multirow{4}{*}{$\begin{array}{l}\text { Grappi and } \\
\text { Montanari } \\
(2011)\end{array}$} \\
\hline & HE2 & I truly feel visiting Amusement park as an escape & \\
\hline & HE3 & I truly enjoy the Amusement park for its own sake & \\
\hline & HE4 & I truly feel delighted while visiting an Amusement park & \\
\hline \multicolumn{4}{|c|}{$\mathrm{cos}$} \\
\hline \multirow{3}{*}{$\begin{array}{l}\text { Sensory } \\
\text { Experience }\end{array}$} & SE1 & \multirow{12}{*}{$\begin{array}{l}\text { Amusement parks make a strong impression on my senses, } \\
\text { visually and in other ways } \\
\text { I find Amusement parks interesting in a sensory way } \\
\text { An Amusement park does not appeal to my senses } \AA \\
\text { An Amusement park induces feelings and sentiments } \\
\text { I do not have strong emotions for Amusement park } \AA \\
\text { An Amusement park is an emotional area } \\
\text { I engage in physical activities and behaviors when I am in an } \\
\text { Amusement park } \\
\text { An Amusement park gives me bodily experiences } \\
\text { An Amusement park is not activity oriented } \AA \\
\text { I engage in a lot of thinking when I am in an Amusement park } \\
\text { An Amusement park does not make me think } \AA \\
\text { An Amusement park stimulates my curiosity and problem } \\
\text { solving }\end{array}$} & \multirow{12}{*}{$\begin{array}{l}\text { Barnes et al. } \\
(2014)\end{array}$} \\
\hline & SE2 & & \\
\hline & SE3 & & \\
\hline & $\mathrm{AE} 1$ & & \\
\hline Affective & AE2 & & \\
\hline Experience & AE3 & & \\
\hline \multirow{3}{*}{$\begin{array}{l}\text { Behavioral } \\
\text { Experience }\end{array}$} & BE1 & & \\
\hline & BE2 & & \\
\hline & BE3 & & \\
\hline \multirow{3}{*}{$\begin{array}{l}\text { Intellectual } \\
\text { Experience }\end{array}$} & IE1 & & \\
\hline & IE2 & & \\
\hline & IE3 & & \\
\hline \multirow{6}{*}{$\begin{array}{l}\text { Tourism } \\
\text { Innovativeness }\end{array}$} & TI1 & $\begin{array}{l}\text { If I heard about a newly available attraction, I would be } \\
\text { interested enough to experiment it }\end{array}$ & \multirow{6}{*}{$\begin{array}{l}\text { Couture et } \\
\text { al. }(2015)\end{array}$} \\
\hline & $\mathrm{TI} 2$ & $\begin{array}{l}\text { In general, I am among the first in my circle of friends to } \\
\text { experiment a new attraction when it appears }\end{array}$ & \\
\hline & TI3 & I experiment more new attractions than my friends do. & \\
\hline & TI4 & $\begin{array}{l}\text { In general, I am ready to experiment new attractions, even if I } \\
\text { have not heard of it yet }\end{array}$ & \\
\hline & TI5 & $\begin{array}{l}\text { In general, I am the first in my circle of friends to know the } \\
\text { new attractions }\end{array}$ & \\
\hline & TI6 & I know more about new attractions than most people do & \\
\hline \multirow{4}{*}{ Desire } & DE1 & I would like to visit an Amusement park while traveling & \multirow{4}{*}{$\begin{array}{l}\text { Song et al. } \\
\text { (2014) }\end{array}$} \\
\hline & DE2 & I wish to visit an Amusement park while traveling & \\
\hline & DE3 & I hope to visit an Amusement park while traveling & \\
\hline & DE4 & $\begin{array}{l}\text { I want to have an extraordinary experience when visiting an } \\
\text { Amusement Park }\end{array}$ & \\
\hline \multirow{3}{*}{$\begin{array}{l}\text { Behavioral } \\
\text { intention }\end{array}$} & $\mathrm{Bl} 1$ & I am willing to visit an Amusement park when traveling & \multirow{3}{*}{$\begin{array}{l}\text { Song et al. } \\
(2014)\end{array}$} \\
\hline & $\mathrm{Bl} 2$ & I intend to visit an Amusement park when traveling & \\
\hline & $\mathrm{BI} 3$ & I plan to visit an Amusement park when traveling & \\
\hline
\end{tabular}


Table 1: Construct Items (Note: ${ }^{\circledR}=$ reverse items.)

\begin{tabular}{|c|c|c|c|c|c|}
\hline Gender & Frequency & Percentage & Age & Frequency & Percentage \\
\hline Female & 271 & $59 \%$ & $18-21$ & 63 & $14 \%$ \\
\hline \multirow[t]{2}{*}{ Male } & 186 & $41 \%$ & $22-25$ & 163 & $36 \%$ \\
\hline & & & $26-35$ & 144 & $32 \%$ \\
\hline Education level & Frequency & Percentage & $36-45$ & 53 & $12 \%$ \\
\hline High School & 94 & $21 \%$ & $45+$ & 29 & $6 \%$ \\
\hline Skilled/professional & 48 & $11 \%$ & $\mathrm{~N} / \mathrm{A}$ & 5 & $1 \%$ \\
\hline Undergraduate & 147 & $32 \%$ & & & \\
\hline \multirow[t]{2}{*}{ Postgraduate } & 168 & $37 \%$ & Monthly Income & Frequency & Percentage \\
\hline & & & $0-550 €$ & 136 & $30 \%$ \\
\hline Marital Status & Frequency & Percentage & $551 €-950 €$ & 107 & $23 \%$ \\
\hline Single & 206 & $45 \%$ & $951 €-1350 €$ & 100 & $22 \%$ \\
\hline Relationship & 157 & $34 \%$ & $1351 €-2500 €$ & 79 & $17 \%$ \\
\hline Married & 85 & $19 \%$ & $>2500 €$ & 30 & $7 \%$ \\
\hline Divorced/widowed & 9 & $2 \%$ & $\mathrm{~N} / \mathrm{A}$ & 5 & $1 \%$ \\
\hline
\end{tabular}

Table 2: Profile of Respondents 


\begin{tabular}{|c|c|c|c|c|c|}
\hline Number of trips & Frequency & Percentage & Number of visits & Frequency & Percentage \\
\hline $\begin{array}{l}\text { Less than once a } \\
\text { year }\end{array}$ & 40 & $9 \%$ & 1-3 times & 130 & $28 \%$ \\
\hline Once a Year & 130 & $28 \%$ & 4-6 times & 174 & $38 \%$ \\
\hline Twice a Year & 177 & $39 \%$ & 7-9 times & 59 & $13 \%$ \\
\hline 3+ times a Year & 110 & $24 \%$ & $10+$ times & 94 & $21 \%$ \\
\hline Duration of trips & Frequency & Percentage & Last visit & Frequency & Percentage \\
\hline Less than a Week & 145 & $32 \%$ & Within last year & 153 & $33 \%$ \\
\hline One to Two Weeks & 264 & $58 \%$ & 1-3 years ago & 164 & $36 \%$ \\
\hline $\begin{array}{l}\text { Two Weeks to a } \\
\text { Month }\end{array}$ & 46 & $10 \%$ & $3-5$ years ago & 73 & $16 \%$ \\
\hline More than a Month & 2 & $0 \%$ & $5-10$ years ago & 67 & $15 \%$ \\
\hline
\end{tabular}

Table 3: Travelling and amusement park visiting habits of respondents 


\begin{tabular}{|c|c|c|c|c|c|}
\hline Latent Variable & Indicator & Loadings & Mean & SD & $t$-statistics \\
\hline \multirow{7}{*}{ Positive Emotions (PE) } & PE1 & 0.839 & 0.838 & 0.024 & $35.425^{\star \star}$ \\
\hline & PE2 & 0.826 & 0.825 & 0.021 & $38.458^{* *}$ \\
\hline & PE3 & 0.835 & 0.834 & 0.021 & $39.445^{\star *}$ \\
\hline & PE4 & 0.883 & 0.883 & 0.014 & $62.018^{\star *}$ \\
\hline & PE5 & 0.648 & 0.647 & 0.028 & $23.504^{\star \star}$ \\
\hline & PE6 & 0.822 & 0.821 & 0.023 & $35.608^{* *}$ \\
\hline & PE7 & 0.845 & 0.844 & 0.017 & $48.304^{* *}$ \\
\hline \multirow{4}{*}{ Enjoyment (EN) } & EN1 & 0.949 & 0.949 & 0.006 & $155.189^{* *}$ \\
\hline & EN2 & 0.931 & 0.931 & 0.014 & $67.297^{\star *}$ \\
\hline & EN3 & 0.869 & 0.868 & 0.017 & $51.386^{\star \star}$ \\
\hline & EN4 & 0.939 & 0.938 & 0.008 & $115.654^{\star *}$ \\
\hline \multirow{3}{*}{ Emotional Involvement (EI) } & El1 & 0.807 & 0.806 & 0.027 & $29.902^{* \star}$ \\
\hline & El2 & 0.908 & 0.908 & 0.010 & $86.614^{\star \star}$ \\
\hline & $\mathrm{El} 3$ & 0.920 & 0.920 & 0.008 & $115.752^{\star *}$ \\
\hline \multirow{4}{*}{ Hedonism (HE) } & HE1 & 0.883 & 0.883 & 0.013 & $67.274^{\star *}$ \\
\hline & HE2 & 0.778 & 0.777 & 0.025 & $30.532^{* *}$ \\
\hline & HE3 & 0.844 & 0.843 & 0.022 & $38.664^{\star *}$ \\
\hline & HE4 & 0.911 & 0.911 & 0.010 & $93.802^{\star \star}$ \\
\hline \multirow{6}{*}{ Tourism Innovativeness ( $\mathrm{TI}$ ) } & $\mathrm{TI} 1$ & 0.832 & 0.832 & 0.012 & $68.254^{\star \star}$ \\
\hline & $\mathrm{TI} 2$ & 0.870 & 0.870 & 0.014 & $61.561^{* *}$ \\
\hline & $\mathrm{TI3}$ & 0.893 & 0.893 & 0.010 & $90.845^{\star *}$ \\
\hline & $\mathrm{Tl} 4$ & 0.786 & 0.786 & 0.020 & $38.579^{* *}$ \\
\hline & TI5 & 0.868 & 0.868 & 0.013 & $65.421^{\star \star}$ \\
\hline & $\mathrm{Tl} 6$ & 0.825 & 0.825 & 0.017 & $47.645^{\star \star}$ \\
\hline \multirow{3}{*}{ Sensory Experience (SE) } & SE1 & 0.804 & 0.802 & 0.037 & $21.654^{\star \star}$ \\
\hline & SE2 & 0.893 & 0.893 & 0.012 & $77.198^{\star *}$ \\
\hline & SE3 & 0.761 & 0.761 & 0.034 & $22.089^{* *}$ \\
\hline \multirow{3}{*}{ Affective Experience (AE) } & $\mathrm{AE} 1$ & 0.778 & 0.776 & 0.033 & $23.25^{\star *}$ \\
\hline & AE2 & 0.821 & 0.821 & 0.026 & $32.056^{\star *}$ \\
\hline & AE3 & 0.751 & 0.749 & 0.038 & $19.792^{* *}$ \\
\hline \multirow{3}{*}{ Behavioral Experience (BE) } & BE1 & 0.931 & 0.930 & 0.013 & $72.316^{\star \star}$ \\
\hline & BE2 & 0.824 & 0.818 & 0.038 & $21.881^{* *}$ \\
\hline & BE3 & 0.405 & 0.403 & 0.094 & $4.301^{\star *}$ \\
\hline \multirow{3}{*}{ Intellectual Experience (IE) } & IE1 & 0.771 & 0.765 & 0.044 & $17.693^{* *}$ \\
\hline & IE2 & 0.643 & 0.635 & 0.071 & $9.077^{\star *}$ \\
\hline & IE3 & 0.862 & 0.863 & 0.034 & $25.707^{* *}$ \\
\hline \multirow{4}{*}{ Desire (DE) } & DE1 & 0.930 & 0.929 & 0.013 & $74.365^{\star \star}$ \\
\hline & DE2 & 0.955 & 0.955 & 0.004 & $213.458^{\star *}$ \\
\hline & DE3 & 0.936 & 0.936 & 0.007 & $135.112^{\star *}$ \\
\hline & DE4 & 0.795 & 0.794 & 0.024 & $33.738^{\star \star}$ \\
\hline \multirow{3}{*}{ Behavioral intention (BI) } & $\mathrm{Bl} 1$ & 0.890 & 0.890 & 0.013 & $66.293^{* *}$ \\
\hline & $\mathrm{BI} 2$ & 0.960 & 0.960 & 0.004 & $214.006^{* *}$ \\
\hline & $\mathrm{BI} 3$ & 0.934 & 0.934 & 0.007 & $130.255^{\star *}$ \\
\hline
\end{tabular}

Table 4: Mean, standard deviation, loadings and $t$-statistics of measurement model (Note: ${ }^{* *} \mathrm{p}<0.01$ ) 


\begin{tabular}{|c|c|c|c|c|c|c|c|c|c|c|c|c|c|}
\hline Item & Mean & SD & $\mathrm{AE}$ & BE & $\mathrm{DE}$ & EI & EN & HE & TI & IE & BI & PE & SE \\
\hline$\overline{A E}$ & 4.853 & 1.524 & 0.784 & & & & & & & & & & \\
\hline BE & 5.334 & 1.344 & 0.453 & 0.755 & & & & & & & & & \\
\hline DE & 4.929 & 1.767 & 0.495 & 0.472 & 0.906 & & & & & & & & \\
\hline El & 4.709 & 1.558 & 0.431 & 0.435 & 0.535 & 0.880 & & & & & & & \\
\hline EN & 5.761 & 1.288 & 0.496 & 0.540 & 0.656 & 0.527 & 0.922 & & & & & & \\
\hline HE & 5.075 & 1.487 & 0.525 & 0.569 & 0.755 & 0.554 & 0.771 & 0.855 & & & & & \\
\hline TI & 3.711 & 1.612 & 0.427 & 0.416 & 0.688 & 0.484 & 0.580 & 0.636 & 0.847 & & & & \\
\hline IE & 3.929 & 1.923 & 0.310 & 0.205 & 0.328 & 0.374 & 0.289 & 0.276 & 0.346 & 0.764 & & & \\
\hline BI & 4.567 & 1.811 & 0.451 & 0.430 & 0.894 & 0.502 & 0.582 & 0.688 & 0.656 & 0.360 & 0.929 & & \\
\hline PE & 5.338 & 1.463 & 0.496 & 0.553 & 0.667 & 0.581 & 0.874 & 0.807 & 0.595 & 0.328 & 0.620 & 0.817 & \\
\hline SE & 5.529 & 1.302 & 0.519 & 0.533 & 0.502 & 0.440 & 0.593 & 0.600 & 0.383 & 0.220 & 0.501 & 0.602 & 0.821 \\
\hline CR & - & - & 0.827 & 0.783 & 0.948 & 0.911 & 0.958 & 0.916 & 0.938 & 0.806 & 0.950 & 0.933 & 0.861 \\
\hline AVE & - & - & 0.615 & 0.570 & 0.821 & 0.774 & 0.851 & 0.731 & 0.717 & 0.584 & 0.863 & 0.667 & 0.675 \\
\hline
\end{tabular}

Table 5: Reliability and validity measures (CR, AVE, and Fornell-Larcker) of variables

Note: Diagonal values are the square root of the average variance extracted (AVE).

$\mathrm{AE}$ - Affective Experience; BE - Behavioral Experience; DE - Desire; El - Emotional Involvement; EN - Enjoyment; HE - Hedonism; TI - Tourism Innovativeness; IE - Intellectual Experience; BI - Behavioral Intention; PE - Positive Emotions; SE - Sensorial Experience 


\begin{tabular}{|c|c|c|c|c|c|c|c|c|c|c|c|}
\hline Construct & $\overline{A E}$ & BE & $\overline{D E}$ & EI & EN & $\mathrm{HE}$ & $\mathrm{TI}$ & IE & $\mathrm{BI}$ & PE & SE \\
\hline \multicolumn{12}{|l|}{$\mathrm{AE}$} \\
\hline BE & 0.648 & & & & & & & & & & \\
\hline DE & 0.609 & 0.509 & & & & & & & & & \\
\hline EI & 0.563 & 0.498 & 0.602 & & & & & & & & \\
\hline EN & 0.606 & 0.596 & 0.706 & 0.589 & & & & & & & \\
\hline HE & 0.655 & 0.657 & 0.840 & 0.637 & 0.837 & & & & & & \\
\hline TI & 0.517 & 0.440 & 0.734 & 0.538 & 0.608 & 0.693 & & & & & \\
\hline IE & 0.423 & 0.270 & 0.360 & 0.426 & 0.299 & 0.295 & 0.391 & & & & \\
\hline BI & 0.554 & 0.460 & 0.964 & 0.563 & 0.624 & 0.765 & 0.706 & 0.407 & & & \\
\hline PE & 0.620 & 0.606 & 0.727 & 0.661 & 0.936 & 0.883 & 0.641 & 0.357 & 0.678 & & \\
\hline SE & 0.708 & 0.758 & 0.598 & 0.537 & 0.696 & 0.722 & 0.437 & 0.257 & 0.596 & 0.705 & \\
\hline
\end{tabular}

Table 6: Heterotrait-Monotrait Ratio (HTMT)

Note: AE - Affective Experience; BE - Behavioral Experience; DE - Desire; EI - Emotional Involvement; EN - Enjoyment; HE - Hedonism; TI - Tourism Innovativeness; IE - Intellectual Experience; BI - Behavioral Intention; PE - Positive Emotions; SE - Sensorial Experience 


\begin{tabular}{|c|c|c|c|}
\hline Variables & $\begin{array}{c}\text { Direct } \\
\text { Effects }\end{array}$ & $\begin{array}{l}\text { Indirect } \\
\text { Effects }\end{array}$ & $\begin{array}{l}\text { Total } \\
\text { Effects }\end{array}$ \\
\hline Positive Emotions $\rightarrow$ Desire & & $0.267^{* *}$ & $0.267^{* *}$ \\
\hline Positive Emotions $\rightarrow$ Hedonism & $0.499^{* *}$ & & $0.540^{\star *}$ \\
\hline Positive Emotions $\rightarrow$ Behavioral intention & & $0.227^{* *}$ & $0.227^{\star *}$ \\
\hline Enjoyment $\rightarrow$ Desire & & $0.144^{* \star}$ & $0.144^{\star \star}$ \\
\hline Enjoyment $\rightarrow$ Hedonism & $0.271^{* *}$ & & $0.271^{* *}$ \\
\hline Enjoyment $\rightarrow$ Behavioral intention & & $0.123^{* *}$ & $0.123^{* *}$ \\
\hline Emotional Involvement $\rightarrow$ Desire & & $0.065^{\star *}$ & $0.065^{\star \star}$ \\
\hline Emotional Involvement $\rightarrow$ Hedonism & $0.122^{* *}$ & & $0.122^{* *}$ \\
\hline Emotional Involvement $\rightarrow$ Behavioral intention & & $0.055^{* *}$ & $0.055^{\star *}$ \\
\hline Hedonism $\rightarrow$ Desire & $0.534^{* *}$ & & $0.534^{* *}$ \\
\hline Hedonism $\rightarrow$ Behavioral intention & & $0.455^{\star \star}$ & $0.455^{\star \star}$ \\
\hline Tourism Innovativeness $\rightarrow$ Desire & $0.348^{* *}$ & & $0.348^{* \star}$ \\
\hline Tourism Innovativeness $\rightarrow$ Behavioral intention & & $0.296^{* *}$ & $0.296^{\star *}$ \\
\hline Sensory Experience $\rightarrow$ Behavioral intention & $0.081^{* *}$ & & $0.081^{* *}$ \\
\hline Affective Experience $\rightarrow$ Behavioral intention & -0.028 & & -0.028 \\
\hline Behavioral Experience $\rightarrow$ Behavioral intention & -0.018 & & -0.018 \\
\hline Intellectual Experience $\rightarrow$ Behavioral intention & $0.075^{* *}$ & & $0.075^{\star \star}$ \\
\hline Desire $\rightarrow$ Behavioral intention & $0.852^{\star *}$ & & $0.852^{\star \star}$ \\
\hline
\end{tabular}

Table 7: Direct, Indirect, and Total effects of latent variables (Note: ${ }^{*} p<0.05 ;{ }^{* *} p<0.01$ ) 